10.2478/cer-2013-0001

\title{
European Union Foreign Direct Investment Outflows to ASEAN Countries
}

\begin{abstract}
The paper analyses foreign direct investment outflows from the European Union to the ASEAN countries. The region of Southeast Asia is very important for the EU in terms of economic cooperation. Previous relations between the European Union and ASEAN countries laid the foundations and became the basis for subsequent business initiatives, first encompassing trade and later investment initiatives. Today the liberalisation of foreign direct investment (FDI) flows is taking place, which has a positive impact on the increase in exports of ASEAN countries and in turn affects the economic development of these countries. The European Union deepens its economic ties with the region through FDI, which results in increased economic interdependence.
\end{abstract}

\section{Introduction}

For the European Union, the developing region of Southeast Asia is an increasingly important recipient of foreign direct investment (FDI). EU corporations seek to invest their capital in this region - a region which has strategic importance for other global investors as well, including Japanese investors. At the same time, the economies of the ASEAN countries also seek to maintain close economic ties with EU corporations. They are interested in ever

\footnotetext{
* Ph.D., University of Łódź, Faculty of Economics and Sociology, Department of World Economy and European Integration
} 
closer and expanding economic and political relations. Thus, FDI from the European Union member states complement and become interwoven in the network of mutual relations existing between these economies, as can be seen in successive UNCTAD reports. This reflects the fact that further liberalisation of FDI flows is occurring at the multilateral level (initiated by the WTO and OECD), at the regional level in the EU-ASEAN framework, as well as at the level of signing bilateral agreements conducive to making direct investments.

This article aims to present and analyse European Union foreign direct investment outflows to ASEAN countries. It should be noted that these countries are distant in geographical as well as economic terms. European companies, however, are locating their places of business in Asian markets. Thus, three important questions arise: firstly - what are the economic determinants linking the European Union and ASEAN countries? Secondly what is the degree of involvement of EU companies in the countries of Southeast Asia? And lastly - what is the impact of European Union foreign direct investment on the ASEAN economies?

\section{Economic determinants linking the European Union and ASEAN countries}

The location of Southeast Asian countries in one geographical region implies their common interests in the socio-political sphere, overcoming backwardness, development of economies and concerns for the economic stability of the region. Thus, a need arose to set up an organisation to group these countries together. The Association of Southeast Asian Nations ${ }^{1}$ (ASEAN) was established in Bangkok on 8 August 1967. The ASEAN was formed to: support economic, social, and cultural growth - the development of the region through cooperation programmes; ensure political and economic stability in the region; and create a forum for resolving intra-regional problems ${ }^{2}$. Furthermore, it was declared that areas of particular importance to mutual cooperation would include: trade, agriculture, industry, transport, and communications (KisielŁowczyc 1994 , pp. 243 - 247).

\footnotetext{
${ }^{1}$ The ASEAN (Association of South-East Asia) consists of 10 countries. Five of them founded the ASEAN: Philippines, Indonesia, Malaysia, Singapore, Thailand. In order of joining ASEAN were: Brunei - 08/01/1984, Vietnam - 07/28/1995, Myanmar and Laos - 23/7/1997, and Cambodia - 04/.30.1999.

${ }^{2}$ Bangkok Declaration, 8 August 1967, www.aseansec.org
} 
What was the EU's reaction and approach to the establishment of this association? Initially, it was rather cautious and there was no significant economic cooperation. It was not until the mid-1990s that a considerable interest in cooperation between the European Union and ASEAN countries occurred. This was due to a number of factors and events, both on a global as well as a regional scale. Firstly, the European Union became aware of the increasing role of the ASEAN countries, as well as their important position and activity in the global economy (their share in the world exports and the increase in European Union trade with ASEAN). They had an significant influence on other world economies at the end of the 20th century. In addition, the high degree of economic dependence of ASEAN economies on trade with industrialised nations should be noted. The activity of the World Trade Organisation (WTO) also had a significant impact on the economic development and subsequent export capabilities of the ASEAN countries (Oziewicz 2001, pp.202-219). In addition, ASEAN countries were characterised by their high potential and the surging growth rates in their economies. This had a considerable impact in the era of globalisation, in which rapid decision making and improving technology are important values. The European Union member states also became aware of an increase in the number of regional trade agreements in Asia and elected not to remain outside the scope of influence in the region. The above-presented declarations and trends were greatly influenced by the economic ties of the United States of America, Japan, and China in the region, which also stimulated the strengthening of relations and economic ties with the region on the part of the European Union, as a strong global economy and an important player in the global economic system. The data concerning the economic ties of both associations confirm these trends (presented later in Section 3).

In October 2006, the European Commission issued the communication: "Global Europe - Competing in the World," in which the ASEAN organization was identified as a priority partner for a free trade agreement and the countries therein as priority markets ${ }^{3}$. The European Union substantiated that position by ASEAN's high growth potential, and the intention of the EU was to realise the highest possible level of trade liberalisation and investment.

The first-ever summit between the European Union and the ASEAN association, which was held on 22 November 2007 in Singapore (the 30th anniversary of the establishment of official EU and ASEAN relations), was aimed at assisting in the achievement of this goal.

\footnotetext{
3 Article 207 and 352 of the Treaty on the Functioning of the European Union and www.eur-lex.europa.eu
} 
Earlier, Asian countries sought to deepen their cooperation within the ASEAN community itself. In January 1992 in Singapore, the desire to establish a free trade area of ASEAN countries called AFTA (ASEAN Free Trade Area) (Witkowska 2008, pp. 89-104) was expressed. At the same time, the agreement on a Common Effective Preferential Tariff (CEPT) was adopted. Thus, the integration processes among ASEAN countries themselves began to intensify. Earlier, in 1977 the Agreement on ASEAN Preferential Trading Arrangements (PTA) was signed within the framework of this association. This agreement constituted the main instrument for the revival of intra-regional trade.

However, the date of 23 April 2007 marked a turning point in the history of the economic cooperation between the European Union and ASEAN, for on that date the Council directed the Commission to initiate negotiations on a free trade area (FTA) with ASEAN. These negotiations were officially opened on 4 May 2007 at a summit held in Brunei ${ }^{4}$.

The conclusion of such an agreement would allow for greater cooperation and contribute to the liberalisation of trade and investment flows (Dobroczyński 2005 , pp. 329 - 339), which would in turn contribute to employment and economic growth. From the European Union perspective, successful conclusion of the FTA negotiations would fulfil the objective of an active European Union policy in this region of the world ${ }^{5}$. However, the political and economic diversity of the countries which were members of ASEAN resulted in the inability to develop a negotiating offer for all ASEAN countries. On the other hand, it should be mentioned that ASEAN countries have manifested little interest in accelerating the FTA negotiations, since there already exists a relative openness of the European Union markets for ASEAN countries and a preferential European Union export system encompassing most ASEAN countries - the Generalised System of Preferences (GSP) and Everything but Arms (EBA) $)^{6}$.

The original objective of signing a free trade agreement by the European Union with the whole block of ASEAN countries is currently unachievable. The European Union has thus focused on concluding bilateral agreements with those countries in the region that are ready to do so (Singapore, Malaysia).

All the above-mentioned events taken together had further implications for the European Union economic policy towards the ASEAN. Earlier trade ties with ASEAN countries were an important starting point for European Union capital investments. They subsequently enabled the establishment of easier and

\footnotetext{
${ }^{4}$ ASEAN - European Parliament, www. europa.eu, 20.04.2012.

${ }^{5}$ ASEAN - Ministry of Economy, www.mg.gov.pl

${ }^{6}$ ASEAN - Ministry of Economy, www.mg.gov.pl
} 
broader economic relations, including the allocation of capital in the form of foreign direct investment. This flow of investment capital is beneficial for both the investor and the recipient of the investment. Certainly, one of the reasons behind reviving the economic cooperation with ASEAN countries is the desire on the part of the European Union Member States to make a profit. However, it is important to realise that the profit-making goal is considered in the long-term perspective. Cheap labour and raw materials still play an important role as factors that contribute to the FDI inflow and the growing trade with the ASEAN region.

On the other hand, the countries of Southeast Asia are associated with a very fast pace of economic growth over recent decades, and their success has depended on the inflow of foreign capital from the developed countries. The European Union has exerted a considerable influence in this regard. Supplying capital in the form of FDI is one of the main factors in the economic development of ASEAN countries. Hence, currently these economies are characterised by an openness to foreign capital. And positive changes in the investment climate (economic, political, social and administrative) have also had a major impact on the size of the flow of FDI. Various incentives are used for this purpose. The most important include financial and fiscal incentives, including tax incentives. The individual countries offering the most attractive incentives attract foreign investors. In developing countries such as the ASEAN states fiscal incentives are mainly used. This is mostly a result of the lack of resources needed to apply financial incentives (Wysokińska 2001, pp. 51-52). Tax vacations or reduced tax rates are used, and the open door policy is also applied (Witkowska 2009, pp. 5-25). Fiscal incentives are negotiated individually by each state. It should be noted, however, that regulations concerning foreign investors are subject to change over time. Foreign investors also have to take into consideration the policy of individual governments with regard to the mandatory share of domestic capital in the company's business operations and to the transfer of profits. Naturally, the situation in the global economy, membership in integration organisations, and bilateral economic agreements have an impact on the decisions regarding liberalisation of the conditions for business activity of foreign investors.

Global and regional ties also impact on the directions of the European Union's FDI flows. The most important forum for such cooperation between the European Union and ASEAN is ASEM. The ongoing political and economic dialogue between the two groups has resulted in the strengthening of the European Union's economic presence in Asia. Thus, the economy is seen as the most important forum of cooperation with the ASEAN countries. The 
strengthening of the EU's position in trade and capital flows in the region is taking place (Borkowski 2011, pp. 540-551).

\section{The degree of involvement of European Union enterprises in Southeast Asian countries}

From the beginning of the 1990s until the year 2000, a gradual increase in European Union investment inflows and outflows could be observed. Figure 1 presents detailed data concerning the total inflow of foreign direct investments to the European Union and their total outflow from the European Union. As a result of the improved macroeconomic situation, foreign investment inflows and outflows received a boost in 2000 and in 2007. In 2007, the value of FDI inflows to the European Union amounted to 857 billion USD, whereas the value of FDI outflows from the European Union came to 1.253 trillion USD. It should be noted that the graph ends as a rising hyperbole, hence there is a reasonable possibility of future increases in European Union investment inflows and outflows in upcoming years.

Figure 1. Total FDI inflows to the European Union and total FDI outflows from the EU in the years 1990 - 2011 (in USD million)

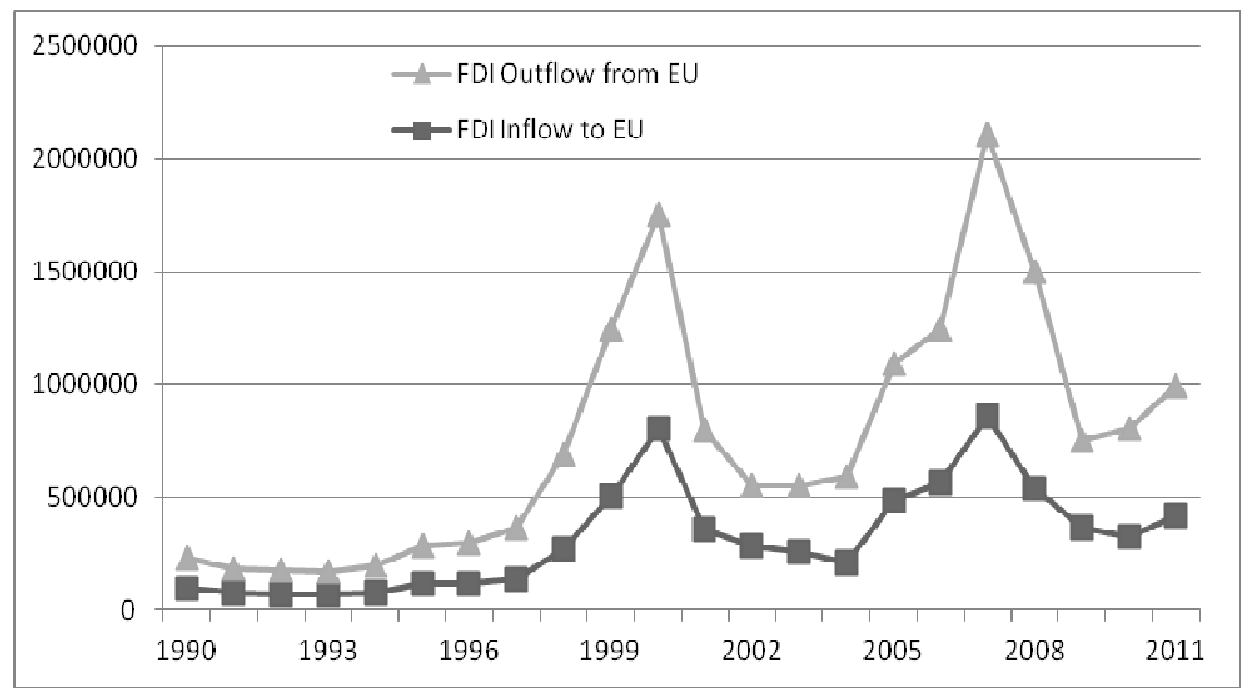

Source: Foreign Direct Investment Statistics - OECD Data, Analysis and Forecasts, www.oecd.org, (09.05.2012) and FDI in figures - May 2012, www.oecd.org, (08.05.2012), and the author's own calculations, EU 15 to 2003, EU 25 (2004 - 2006), EU 27 from 2007. 
There is no doubt that trans-national corporations, including European Union corporations, seek to eliminate trade barriers in order to maximise profits. It is clear as well that they are also interested in the existence of clear and stable rules governing the world market (Marzęda 2007, pp. 304-307).

On the other hand, ASEAN countries are mainly FDI recipients. They pursue an open admission policy towards foreign investments and boast a favourable investment climate. A stable macroeconomic situation, a large labour market - employees willing to work and a large market of potential employees, a clear and transparent policy and clear rules on the admission of foreign direct investment, as well as the existence of agencies encouraging investment in the region are important for foreign investors ${ }^{8}$.

The European Union is the largest investor in ASEAN countries. In the years $2001-2005,27 \%$ of total FDI value in ASEAN countries came from the European Union, and in the years 2006 - 2008 EU enterprises invested on average 10.4 billion Euro annually ${ }^{9}$. Eurostat data indicates that the UK and Holland are the largest European Union investors in ASEAN countries.

Eurostat data also shows that Singapore is a key partner in the receipt of European Union FDI in the ASEAN region. The EU gained in importance as a leading foreign investor in this country in the years $1995-2005$, when the its share in foreign direct investment in the region increased from $31 \%$ to $43 \%$. In 2009 , the total value of investment came to 95.8 billion Euro. More than 8,500 enterprises from the European Union (manufacturing sector, financial and insurance sectors) are based in Singapore. The countries that are the largest capital investors in Singapore are Switzerland, Holland, and the UK.

The European Union is also the source of the largest FDI inflow into Malaysia, where the invested capital amounted to 24.7 billion Euro and was mainly located in the manufacturing sector. The largest investors in Malaysia are the UK, France, Finland, Holland and Germany. Malaysia ranks second in the ASEAN region after Singapore as the most sought-after target location for FDI $^{10}$.

In Indonesia, there are approximately 700 European enterprises which specialise in the production of oil and gas, mining, and banking. The capital

\footnotetext{
${ }^{7}$ First ASEAN - OECD Investment Policy Conference, OECD, www.oecd.org/document/, (09.05.2012).

${ }^{8}$ Post - Crisis FDI Inflows to ASEAN, ASEAN - OECD Investment Policy Conference, 18-19 November 2010, ASEAN Secretariat, www.aseansec.org

${ }^{9}$ ASEAN, European Parliament, www.circa.europa.eu

${ }^{10}$ Eurostat, www.epp.eurostat.ec.europa.eu
} 
from the European Union invested into Indonesia in 2009 amounted to 2 billion $\mathrm{USD}^{11}$.

The European Union is also one of the most important investors in Vietnam. EU investments in Vietnam to a large extent concentrate in the hightech and service sectors. In 2010, the largest European Union investors in Vietnam were: Holland (2,270.7 million USD), Luxembourg (110.3 million USD), Slovakia (100 million USD), the UK (56.4 million USD), Germany (37.5 million USD), France (17.4 million USD), Denmark (11.7 million USD) and Italy (7.2 million USD) $)^{12}$.

It is estimated that commercial networks of European Union companies will also continue to invest in the countries and regions that have the greatest demand development potential in the coming years. These will include the countries with a high rate of economic growth and poor distribution infrastructure, which encompasses the following ASEAN countries: Indonesia, Thailand, Malaysia and Singapore. Despite the high risk and large cultural differences, due to the demographic potential and good prospects for growth in consumer wealth, these countries will be seen as strategic target markets by international commercial chains in the coming years (Nowakowski 2005, pp. 228-233).

It is worth noting that the highest degree of internationalisation - as a host country for overseas companies - including the largest share of foreign companies in the economy, is observed, apart from Ireland, Belgium and Luxembourg, in Asian countries such as Hong Kong and Singapore (Bossak 2006, pp.188-189).

In 2007, during the period of rapid increase in investment outflows from the European Union (compare Figure 1), the ASEAN countries also experienced an investment increase in their region due to the inflow of 15 billion USD. The following graph, Figure 2, depicts the decline in EU FDI inflows in the region which resulted from the global financial crisis.

\footnotetext{
${ }^{11}$ Eurostat, www.epp.eurostat.ec.europa.eu

${ }^{12}$ Vietnam, Ministry of Foreign Affairs, www.msz.gov.pl
} 
Figure 2. FDI inflows to ASEAN countries from the European Union in the years 2006 - 2009 (in USD million)

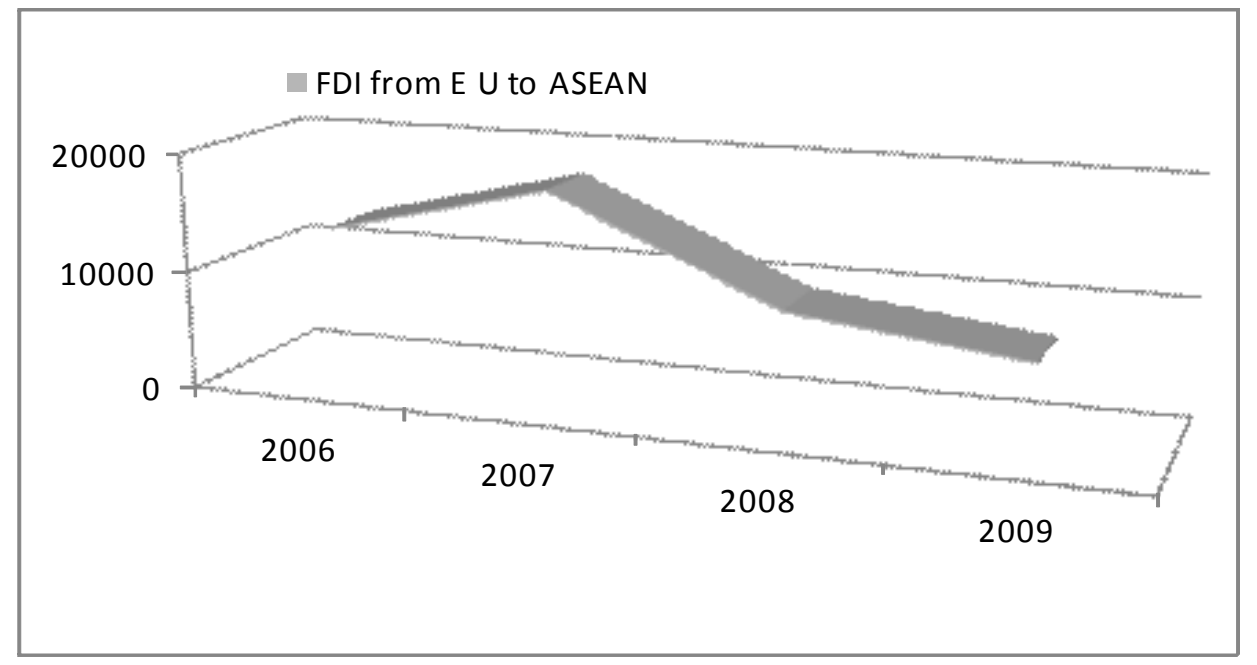

Source: Post - Crisis in FDI Inflows to ASEAN, ASEAN - OECD Investment Policy Conference, 18-19 November 2010; ASEAN Secretariat, www.aseansec.org, and the author's own calculations.

Figure 3 presents FDI flows directed from both the European Union and the world to ASEAN countries in the years 2006 and 2009. In 2006, ASEAN countries received 13 billion USD from the EU, which constituted 23.4\% of total FDI inflows to ASEAN countries. In 2009, ASEAN countries received 7.3 billion USD from the European Union, which constituted 18.4\% of global FDI inflows to ASEAN countries. Direct investments from the European Union flowing to ASEAN in 2009 constituted $1.88 \%$ of total EU investment ${ }^{13}$.

It should be noted that the dwindling global and European Union investment inflows to ASEAN countries in 2009 were caused, inter alia, by the ongoing economic crisis. Many European enterprises had limited access to credit at that time, and they were uncertain of their profits in such far-away countries. Additionally, the macroeconomic situation in individual European Union member states changed dramatically. The bad economic mood and government predictions concerning the future of the economy also played an important part. These took their toll on investing corporations, which were faced with a choice to resign from their investment plans completely, or only partially. Thus, ASEAN countries observed a drop in European Union FDI inflows.

\footnotetext{
${ }^{13}$ Post - Crisis FDI Inflows to ASEAN, ASEAN - OECD Investment Policy Conference, 18-19 November 2010, ASEAN Secretariat, www.aseansec.org and the author's own calculations.
} 
Figure 3. The European Union and global FDI inflows to ASEAN countries in the years 2006 and 2009 (in USD million)

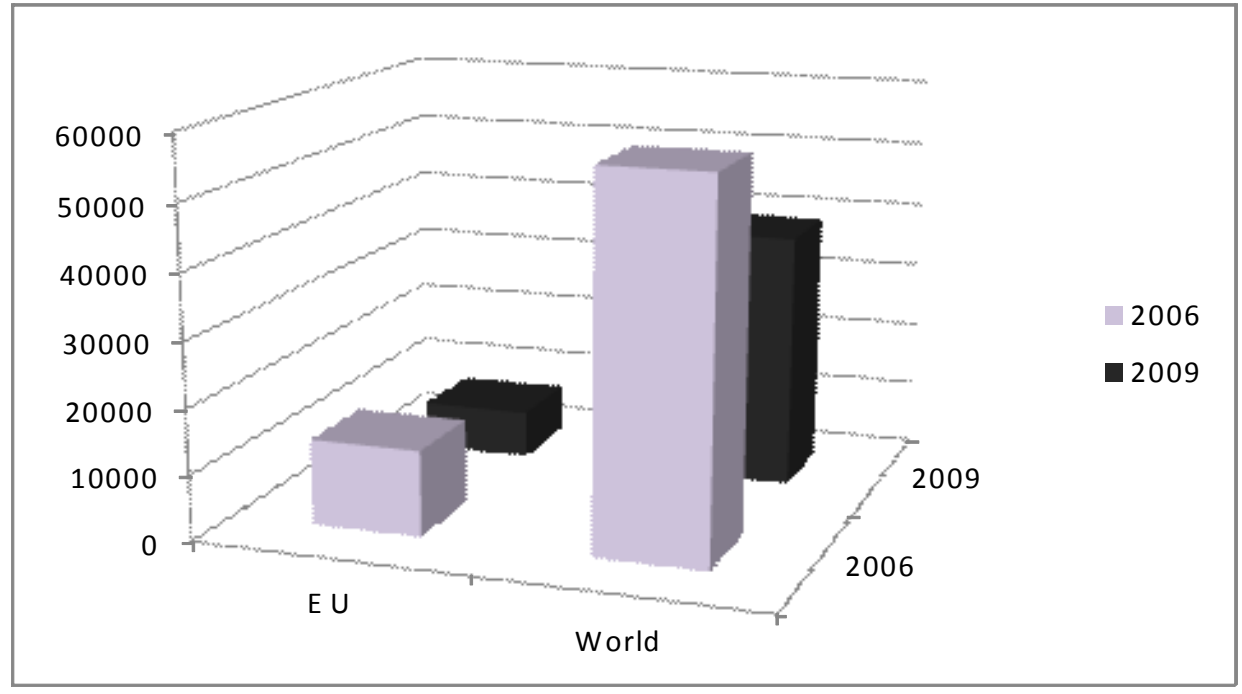

Source: Post - Crisis FDI Inflows to ASEAN, ASEAN - OECD Investment Policy Conference,

18-19 November 2010; ASEAN Secretariat, www.aseansec.org, and the author's own calculations.

The European Union (27), intra -ASEAN, USA and Japan continued to be the top providers of ASEAN FDI inflows in 2010. The European Union contributed $22,4 \%$, followed by intra-ASEAN (16\%), the USA $(11,3 \%)$ and Japan $(11 \%)^{14}$.

\section{The impact of FDI from the European Union on ASEAN economies}

Foreign direct investment coming from the European Union has a positive impact on ASEAN countries. There are at least three aspects of key importance:

1. Increased FDI inflow from the European Union results in an increase in exports of ASEAN countries, which notably affects their balance of trade;

2. Supply of capital in the form of FDI becomes one of the main factors in the economic development of ASEAN countries;

${ }^{14}$ ASEAN: FDI inflows, by Source country (in US \$ milion) for periods indicated; ASEAN Investment Statistics Database, www.aseansec.org 
3. With the use of FDI, the EU strengthens its economic ties with the region, which results in increased economic interdependence.

Therefore, it can be concluded that European Union foreign direct investment boosts the trade of recipient countries. This can be explained in more detail by the fact that foreign direct investments expand trade opportunities in terms of export from the country which is the recipient of the investment (an ASEAN country) - to the home country of the corporation in the first instance, and then to other European Union member states, as well as third countries outside the EU. The macroeconomic data on trade confirms this trend. In the years $2004-2008$, trade in goods and services between the ASEAN and the European Union increased by more than $25 \%$ and amounted to 175 billion Euro. Following a short-term decline brought on by the economic crisis, in recent years the import of goods from ASEAN countries to the EU has been growing steadily. It reached 93 billion Euro (which comprised 5.5\% of total European Union imports) in 2011. The European Union exports to ASEAN countries amounted to 68 billion Euro, which comprised $4.5 \%$ of EU exports ${ }^{15}$.

However, in 2009 a crisis-induced decline in both European Union imports and exports to ASEAN countries was observed. Importantly, in 2011 the European Union recorded a trade deficit totalling 150 billion Euro, and its trade deficit with ASEAN countries amounted to 20 billion Euro.

The increased exports of ASEAN countries translate into a positive balance of trade, and the balance with the European Union is thus strengthened. The EU and ASEAN trade turnover is asymmetrical, as the European Union market accounts for approximately $60 \%$ of exports from the ASEAN states, whereas ASEAN exports constitute only $2.5 \%$ of European Union imports. The average EU imports from the ASEAN in the years 2007 - 2011 constituted approximately $5.6 \%$ of total EU imports. European Union exports to ASEAN countries in the years $2007-2011$ constituted on average approximately $4 \%$ of total EU exports ${ }^{16}$.

FDI inflows from the European Union have an impact on the economic development of ASEAN countries. Capital inflow into investment recipient countries is a key factor in improving the balance of payments in the short term. Other factors, such as new technologies, management and organisation methods, as well as know-how and skills also become transferred by means of foreign direct investment. Trade boosted by FDI also yields additional profits for

\footnotetext{
${ }^{15}$ EU trade with main partners (2011), European Commission, http://trade.ec.europa.eu and the author's own calculations.

${ }^{16}$ The author's own calculations, based on the data on the EU's trade balance with the ASEAN, European Commission, http://trade.ec.europa.eu
} 
producers of goods and services, and this trade revenue in turn translates into an improved public budget. Another important effect is an increase in employment in the recipient country of the investment. Corporations provide a workplace for the local workforce, i.e. create jobs. This is especially true in the case of greenfield type investments (typical of developing countries), i.e. the creation of a company from the ground up, since they cause an immediate increase in employment. Companies competing in the domestic markets also seek to stimulate efficiency gains. The transfer of innovations and new technologies accompanying FDI contribute directly to this process. The inflow of capital into a country in the form of FDI causes an increase in its competitiveness in the market, and later an increased inflow of investments into this country. Taking into account the two key factors brought about by FDI - increased trade and modern technology - direct investments may improve the international competitiveness of a particular country. All the above mentioned factors have an impact on the improvement of the situation in a particular recipient country and, in general, on the development of individual economies. However, in order for these countries to develop economically, a further change is needed restructuring of industries. Only this step, followed by increased production, provides sustainable results, and so it has been in the case of the FDI inflows into the ASEAN states.

Data on the flow of FDI and trade confirm the trend toward strengthening relations and economic ties between the European Union and the region of Southeast Asia. Both capital investment as well as trade continue to take place, despite the negative changes in economic conditions (i.e. the current crisis). Thus, this region is important for further European Union international economic cooperation. This is due to the consistent economic policy of the EU, which seeks to build sustainable and multi-faceted economic and capital ties in the region in order to strengthen its economic and political position. By virtue of its strong interregional ties, the European Union affirms its position as a strong global economic player and its position as a leader in the global economic system.

\section{Conclusions}

The markets of highly developed countries such as the European Union countries are opening up to trade with the markets of less developed countries. As regards the ASEAN countries, this is possible in part due to the abolition of barriers to trade, and for this reason the flow of capital from highly developed economies (the European Union) to less developed ones (ASEAN) is increasing. 
The European Union is tightening political and economic cooperation with the ASEAN countries. The policy of multi-faceted economic, trade, and capital ties, e.g. in the form of foreign direct investment, is consistently being promoted. In addition to the growing trade, the increased flow of FDI is evidence of much closer European Union relations with ASEAN countries.

In the countries of Southeast Asia, the beneficial effects that result from the liberalisation and internalisation of economies in this region can be seen. This is illustrated, inter alia, by the example of ASEAN integration. From the perspective of these countries, cooperation with the EU is highly beneficial. Owing to foreign direct investment from the European Union, ASEAN countries acquire, for example, modern technology. These investments can also boost economic growth and development. In this way, ASEAN countries are strengthening their position and the position of the whole region in the world arena. On the other hand, the European Union undoubtedly puts forward cooperation initiatives, including the establishment of the FTA, in order to enhance the export opportunities of its own producers. It should be noted also that the strengthening of cooperation between the European Union and ASEAN countries brings these latter countries "closer" to the EU.

The degree of European Union economic involvement in ASEAN countries is significant, and economic relations between the two integration groups are correct. The EU side, however, seeks to deepen them further in the near future. This strengthening of economic cooperation occurs, inter alia, by means of trade and foreign direct investment. The amount of capital invested in the form of European Union FDI in ASEAN countries in 2009 amounted to 7.3 billion USD, which constituted approximately $1.88 \%$ of total European Union investments. This amount also constituted $18.4 \%$ of total global FDI inflows directed to the ASEAN countries.

The inflow of FDI from the European Union results in increasing exports of the ASEAN countries, which notably affects their balance of trade. In addition, capital inflow in the form of FDI from the European Union has become one of the main factors contributing to the economic development of ASEAN countries. These measures lead to deepening economic ties between the EU, where the capital comes from, and the host ASEAN countries, which also contributes to economic interdependence. 


\section{References}

Articles 207 and 352, Treaty on the Functioning of the European Union

ASEAN: FDI inflows, by Source country (in USD million) for periods indicated; ASEAN Investment Statistics Database, www.aseansec.org

ASEAN - Ministry of Economy, www.mg.gov.pl

ASEAN - European Parliament, www. europa.eu

ASEAN, European Parliament, www.circa.europa.eu

Bangkok Declaration, 8 August 1967, www.aseansec.org

Borkowski P.J. (2011), ASEM jako przejaw globalizacji (ASEM as a symbol of globalisation) [in:] Nakonieczna, J., Zajączkowski, J. (ed.), Azja Wschodnia i Azja Południowa $w$ stosunkach międzynarodowych, Warsaw University Press, Warsaw

Bossak J.W. (2006), Systemy gospodarcze a globalna konkurencja (Economic systems and global competition), Warsaw School of Economics, Warsaw

Dobroczyński M. (2005), Przeksztatcenia międzynarodowej rzeczywistości ekonomiczno politycznej (Transformatiion of the international economic-political reality), Adam Marszałek Publishing House, Warsaw - Toruń

EU trade with main partners (2011), European Commission, http://trade.ec.europa.eu

Eurostat, www.epp.eurostat.ec.europa.eu

First ASEAN - OECD Investment Policy Conference, OECD, www.oecd.org/document/

Foreign Direct Investment Statistics - OECD Data, Analysis and Forecasts, www.oecd.org, and FDI in figures - May 2012, www.oecd.org

Marzęda K. (2007), Proces globalizacji korporacyjnej (The process of corporate globalization), Oficyna Wydawnicza Branta, Bydgoszcz - Warsaw - Lublin

Nowakowski M.K. (2005), Biznes międzynarodowy. Od internalizacji do globalizacji (International Business. From internalization to globalization), Warsaw School of Economics, Warsaw

Oziewicz E. (ed.) (2001) Procesy integracyjne we współczesnej gospodarce światowej (Integration processes in the contemporary world economy), $\mathrm{PWN}$, Warsaw

Post - Crisis FDI Inflows to ASEAN, ASEAN - OECD Investment Policy Conference, 18-19 November 2010, ASEAN Secretariat, www.aseansec.org

EU's trade balance with ASEAN, European Commission, http://trade.ec.europa.eu

EU's trade with main partners (2011), European Commission, http://trade.ec.europa.eu

Vietnam, Ministry of Foreign Affairs, www.msz.gov.pl 
Witkowska J. (2008), Regional Integration and Capital Mobility in the World Economy; Experiences of the European Union, NAFTA and AFTA, 'Comparative Economic Research Central and Eastern Europe', Volume 11, No.1/2/2008, Łódź University Press, Łódź

Witkowska J. (2009), Policies with Respect to Foreign Investors in the New Member States of the European Union and in the Developing Countries of Asia: Comparative Aspects, 'Comparative Economic Research Central and Eastern Europe', Vol 12, No1/2/2009, Łódź University Press, Łódź

Wysokińska Z. (2001), Konkurencyjność w międzynarodowym i globalnym handlu technologiami (Competition in international and global trade in Technologies), PWN, Warsaw - Łódź

\section{Streszczenie}

\section{BEZPOŚREDNIE INWESTYCJE ZAGRANICZNE UNII EUROPEJSKIEJ LOKOWANE W KRAJACH ASEAN}

Artykut poddaje analizie bezpośrednie inwestycje zagraniczne pochodzace z Unii Europejskiej lokowane $w$ krajach ASEAN. Dla UE region Azji Potudniowo Wschodniej choć daleki w sensie geograficznym, jest bardzo ważny z punktu widzenia wspótpracy gospodarczej. Wcześniejsze kontakty między Unia Europejska a ASEAN byty podstawa - baza do późniejszych inicjatyw biznesowych, w tym handlowych a następnie inwestycyjnych. Rozwijajacy się region Azji Południowo - Wschodniej dla Unii Europejskiej jest coraz bardziej znaczacym odbiorca bezpośrednich inwestycji zagranicznych. Firmy europejskie znajduja miejsce na swoja działalność na tych azjatyckich rynkach. Z drugiej strony również gospodarki krajów ASEAN staraja się utrzymywać bliskie stosunki gospodarcze z korporacjami pochodzacymi z krajów Unii Europejskiej. Zależy im na bliskich $i$ rozwijających się stosunkach politycznych i gospodarczych.

Celem badania byto również pokazanie wpływu bezpośrednich inwestycji zagranicznych pochodzacych z Unii Europejskiej na gospodarki ASEAN. Ma to zwiazek z obecnie postępujaca liberalizacja przeptywu bezpośrednich inwestycji zagranicznych. Wptywaja one korzystnie na zwiększenie eksportu krajów ASEAN, a co w konsekwencji może wptywać na rozwój gospodarczy tych krajów. Poza tym poprzez lokowanie kapitatu $w$ formie bezpośrednich inwestycji zagranicznych Unia Europejska zacieśnia więzi ekonomiczne z tym regionem świata, co skutkuje zwiększeniem wspótzależności ekonomicznych. 